\title{
The effects of corporate governance on information disclosure, timeliness and market
}

\section{participants' expectations.}

\author{
Wendy Beekes, Philip Brown, Germaine Chin and Qiyu Zhang*
}

This version: 1 June 2016

* Wendy Beekes is from Lancaster University, Philip Brown and Germaine Chin are from the

University of Western Australia, and Qiyu Zhang is from Lancaster University.

Address for correspondence:

Dr Wendy Beekes

Department of Accounting and Finance,

Management School,

Lancaster University,

Lancashire

LA1 4YX

Email: w.beekes@lancaster.ac.uk

Tel: 44 (0) 1524593623

Fax: $44(0) 1524847321$

\section{ACKNOWLEDGEMENTS}

We are indebted to David Scott for his assistance in accessing the SEDAR website. We thank Linda Myers, Ken Peasnell, Kwok Tong Soo and Steve Young for useful comments. This is a heavily revised version of the paper entitled 'Do Better-Governed Firms Make More Informative Disclosures? Canadian Evidence.' Earlier versions of this paper were presented at the Accounting and Finance Association of Australia and New Zealand conference, the Centre for Corporate Governance Research International Corporate Governance conference, the British Accounting Association Corporate Governance Special Interest Group Conference and the European Accounting Association Annual Congress. This work was supported by the Leverhulme Trust under Grant F/00 185/W - Corporate governance, disclosure policies and the timeliness of price discovery. 


\title{
The effects of corporate governance on information disclosure, timeliness and market participants' expectations.
}

\begin{abstract}
We examine whether corporate governance has an influence on Canadian firms' disclosure practices, the timeliness of price discovery and market participants' (analysts') behaviour in a study of Canadian listed companies for the period 2002-2007. Our results confirm other evidence that better-governed firms make more disclosures and their stock price discovery is more timely. This suggests a complementary association between corporate governance quality and disclosure. However, despite releasing more documents overall, we find releases from better-governed firms to the stock market are made on a less timely basis, perhaps implying a more conservative approach to the release of disclosures to the stock market. We further find that analyst following is positively associated with a firm's corporate governance quality. In addition, for firms with better corporate governance, analysts' Earnings Per Share forecasts are more accurate and less dispersed. More detailed analysis reveals only certain components of corporate governance are associated with disclosures and overall transparency. Taken as a whole, our results confirm corporate governance can play a significant role in determining the efficiency of a country's equity market.
\end{abstract}

JEL: G30; G38; M40.

Keywords: Corporate governance; Disclosure frequency; Analysts' forecasts; Price discovery; Timeliness 


\section{Introduction}

This paper investigates the association of Corporate Governance (CG) quality and differences in disclosures, information timeliness and the properties of analyst earnings forecasts. How a firm is governed and monitored is likely to affect its transparency and level of disclosure to the market (Hermalin and Weisbach, 2012). Good CG could be either a complement or a substitute for firm's disclosure practices.

Our key research questions are: 'Is better quality CG a complement or a substitute for disclosure and information timeliness?' and 'Which specific aspects of CG are more influential on firm's disclosure behaviour?' Building on prior research (Beekes and Brown, 2006, hereafter, BB06; Aman et al., 2011; Hass et al., 2014; Liu, 2012; Lim et al., 2014; Beekes et al., 2015; 2016) we re-investigate the relation between CG and a number of measures of the quantity of disclosure and the informativeness of those disclosures. We chose to investigate Canada to enable direct comparison and benchmarking of our initial results for the overall CG measure with BB06 who examine Australia. Canada is similar to Australia in terms of its legal tradition and approach to CG, which is also adopted on a "comply or explain' basis. In addition, Canada has a similar industry composition to Australia with a large number of resource firms.

We use the Board Shareholder Confidence Index (BSCI) from the Clarkson Centre for Business Ethics and Board Effectiveness at the Rotman School of Management (CCBE) to measure CG. This unique dataset scores CG of firms listed on the S\&P/TSX Composite Index on an annual basis. There are six measures of CG: (i) Board independence; (ii) Directors' Ownership; (iii) Board and Committee Structure; (iv) Board Evaluation Process and Directors' Compensation; (v) Board Decision Output and (vi) Total CG. 
Several measures of disclosure and informativeness are used from prior literature: Firstly, the number of documents released to the stock exchange (BB06; Beekes et al., 2015; 2016). Secondly, the timeliness of document disclosures to the exchange (Beekes and Brown, 2007; Beekes et al., 2015; 2016). These measures focus exclusively on the releases made by the firm to the Toronto Stock Exchange (TSX) (i.e. information from the firm). We also examine how quickly value relevant information about the firm's performance is incorporated into the firm's share price (BB06; Beekes and Brown, 2007; Beekes et al., 2015; 2016). Finally, we examine the quality of information from a users' (analysts') perspective. Following BB06 and Aman et al., (2011), we examine the forecast error (signed and absolute value) and dispersion in analysts' Earnings Per Share (EPS) forecasts, and the level of analyst following. Much prior work (a notable exception of which is Aman et al., 2011) has focused on an overall measure of CG, without specific consideration of the underlying aspects of CG.

Using a sample of Canadian firms from 2002 to 2007, we find Canadian firms' CG is associated with disclosure: better CG is associated with more disclosures and more timely price discovery. Further, we find disclosures to the stock market from better-governed firms are made on a less timely basis relative to other firms. We attribute this result to greater monitoring and conservatism in firms with better CG structures. Canadian firms with better CG are also found to attract greater analyst following, and EPS forecasts for these firms are more accurate with less dispersion in forecasts.

Our study contributes to CG and disclosure research by further investigation of the relation between CG and properties of disclosure and timeliness, and analyst forecasts. We specifically examine which components of CG are important for disclosure and provide a richer insight into which aspects of $C G$ are complements and which are substitutes with disclosure and timeliness, and the quality of information available about a firm in the market. 
The remainder of the paper is organized as follows: Section 2 discusses related literature and develops the hypotheses. This is followed by section 3 which describes the sample and data. Section 4 outlines our research methods. Section 5 discusses our results and the final section concludes the paper.

\section{Hypothesis Development}

\subsection{Agency Theory and Corporate Governance}

Agency theory refers to the relationship between the principal (the shareholders) and their agent (the firm's manager). In this relationship, there are conflicting interests between the shareholder and manager, and both parties are assumed to act in their own self-interest. The level of information asymmetry between the shareholder and manager inevitably means the manager's actions are hidden from the shareholders, leading to agency costs such as those resulting from empire building, shirking and excessive consumption of perquisites. The manager may be provided with observable incentives (e.g. cash bonuses and share options) in an attempt to align the respective interests, and there may be substantial monitoring costs (e.g. for an external audit of financial statements).

Because contracting in the agency relationship is incomplete in the sense that it cannot cover all future contingencies, and the enforcement of contracts is costly (Hart, 1995), CG processes and structures can play a useful role in resolving agency conflicts. The Organisation for Economic Co-operation and Development (OECD) (2004, p.11) identifies CG as: "involv[ing] a set of relationships between a company's management, its board, its shareholders and other stakeholders. CG also provides the structure through which the objectives of the company are set, and the means of attaining those objectives and monitoring performance are determined." Whilst there is no generally accepted theory of CG (Larcker et 
al., 2007), good CG can be perceived as aligning the shareholders' and managers' best interests.

\subsection{Corporate Governance in Canada}

Companies may incorporate under provincial or federal statutes in Canada. CG requirements under both of these statutes are comparable as directors are required to fulfil their role with a duty of care (i.e. act with due care and diligence) and a duty of loyalty (i.e. act in the best interests of the firm). The key sources of CG requirements arise from the Canada Business Corporations Act, and also from the policies and rules of the Canadian Securities Regulators. ${ }^{1}$ The CG guidance in Canada is adopted on a 'comply or explain' basis (as in other countries for example, Australia and the UK).

For a firm to follow best practice under National Policy 58-201 Corporate Governance Guidelines, it would have: (i) a board of directors comprising of a majority of independent members, (ii) a separate chairman of the board or lead independent director, (iii) regular meetings of independent directors without the presence of management or non-independent directors, (iv) a written board mandate, (v) position descriptions for the board's chair, and the chair of each board committee, and the CEO, (vi) orientation training for new directors and the opportunity for continuing education for all directors, (vii) a written code of conduct and ethics, (viii) a nomination committee with independent director membership; (ix) a compensation committee with membership comprising solely independent directors, (x) a process for determining skills and competences of the board, and a regular assessment of the effectiveness of the board of directors, and its committees, along with each individual

\footnotetext{
1 The specific rules and policies are: National Instrument 51-102 - Continuous Disclosure Obligations, Multilateral Instrument 52-109 - Certification of Disclosure in Issuers Annual and Interim Filings, National Instrument 52-110 - Audit Committees, National Instrument 58-101 - Disclosure of Corporate Governance Practices, National Policy 58-201 - Corporate Governance Guidelines and Multilateral Instrument 61 - 101 Protection of Minority Security Holders in Special Transactions.
} 
director (Ontario Securities Commission, 2005a). ${ }^{2}$ To comply with National Instrument 52110 - Audit Committees (effective from July 2004 onwards), firms must establish an audit committee with a minimum of three members, all of whom are expected to be financially literate and independent (Ontario Securities Commission, 2004). The audit committee should oversee the work of the external auditor and approve any non-audit work to be completed by the external auditor. The monitoring provided by a firm's CG could impact on the firm's disclosure strategy.

\subsection{The Role of Disclosure}

Theory suggests disclosure is important to reducing information asymmetry in the agency relationship (Jensen and Meckling, 1976). Disclosure helps investors identify 'good' from 'bad' firms (Akerlof, 1970). Frequent disclosure of information to the stock market is important to keep investors informed of ongoing firm performance and upcoming developments. Through greater or more effective disclosure firms can increase their attractiveness to potential investors and consequently reduce their cost of capital (Botosan, 1997). Indeed, it has been argued that if there is greater information disclosure and a firm is more transparent, more institutional investors and analysts may be attracted to the firm (Lang and Lundholm, 1996; Botosan, 1997; Healy et al., 1999). Greater disclosure could also make it more difficult for insiders to commit fraud (Hermalin and Weisbach, 2012).

Despite the aforementioned benefits of disclosure, more disclosure is not always a good thing. Indeed as Hermalin and Weisbach (2012) argue it may not necessarily be in the shareholders' best interests to have complete disclosure as they will need to compensate managers for this high level of disclosure. For example, managers may also be forced to

\footnotetext{
${ }^{2}$ Companies are also provided with guidance on the required disclosures under National Instrument 58-101 Disclosure of Corporate Governance Practices and also by the TSX as to what represents good CG disclosure (Ontario Securities Commission, 2005b; TSX, 2006).
} 
reveal something that they would prefer to keep secret for opportunistic reasons (Kothari et al., 2009). Moreover full disclosure could reveal information that would leave the firm vulnerable to proprietary costs (Verrecchia, 1983). Thus there can be significant costs associated with disclosure and firms may prefer to retain value-relevant information within the organization. In our study, we take the view that timely and accurate disclosure of information is important to ensure relevant information is available to all users and we assume that greater disclosure is better.

\subsection{Corporate Governance and the Quantity of Disclosure}

Differences in CG of individual firms result in different levels of monitoring which could have a bearing on the disclosure practices adopted. The OECD guidelines suggest that better CG should ensure more timely and accurate disclosure practices leading to greater transparency, i.e. a complementary relation between CG and disclosure (OECD, 2004). Results from prior studies also indicate better $\mathrm{CG}$ is associated with greater disclosure (Bujaki and McConomy, 2002; Ajinkya et al,, 2005; BB06; Li et al., 2012). Correspondingly, firms with weaker CG are found to be associated with lower disclosure levels (Bassett et al., 2007; Ettredge et al., 2011). Therefore our first hypothesis (stated in the alternative form) is:

H1: The quality of the firm's CG is positively associated with the quantity of disclosure to the stock market.

\subsection{Corporate Governance and the Timeliness of Information}

In addition to the quantity of disclosure, the timeliness of such disclosures (i.e. how quickly information is revealed) is also an important characteristic for information to be useful to investors. Under National Policy 51-201 Disclosure Standards, companies are legally obliged 
to disclose material information on a timely basis $^{3}$ and the importance of timely information is emphasised by stock exchange regulators (International Organization of Securities Commissions, 2002; TSX, 2004a). The TSX "Policy Statement on Timely Disclosure" states:

"Public confidence in the integrity of the Exchange as a securities market requires timely disclosure of material information concerning the business and affairs of companies listed on the Exchange, thereby placing all participants in the market on an equal footing,.. Material information is any information relating to the business and affairs of a company that results in or would reasonably be expected to result in a significant change in the market price or value of any of the company's listed securities," (TSX, 2004a, p. 1, 2) [emphasis added].

In addition the TSX policy statement provides examples of events or information which may be material and require additional disclosure to the market, such as changes in borrowing, ownership, capital structure or company prospects. Managers can influence the timing of information releases to the stock market and therefore $\mathrm{CG}$ has a vital monitoring role in ensuring disclosures are made on a timely basis.

We use two measures of timeliness; firstly, the timeliness of documents released to the TSX (i.e. how quickly the firm releases documents to the TSX) and secondly, the timeliness of prices (i.e. the speed with which value relevant information relating to the annual earnings performance is incorporated into share prices over the course of the year). Whilst managers have little control over how quickly information is reflected into prices, they do control the timing and quantity of information which is released to the market, which will ultimately affect how quickly value relevant information is reflected in share prices. Prior work on a

\footnotetext{
${ }^{3}$ There are some exceptions to this requirement for immediate disclosure of material information when there would be release of information which would be detrimental to the company (e.g. in the case of ongoing negotiations or completion of a particular transaction), Ontario Securities Commission (2002).
} 
cross-country basis has found better-governed firms are associated with more timely document release to the stock exchange (Beekes et al., 2016), although no association between CG and the timeliness of documents was found in Australia (Beekes et al., 2015). With regard to the association between CG and the timeliness of price discovery, BB06 and Beekes et al., (2015) found a complementary relation for Australian firms but Aman et al. (2011) find is a substitution relation for Japanese firms. In a cross country study Beekes et al. (2016) find CG is associated with less timely prices which they attribute to market participants' inability to process the greater quantity of information released from bettergoverned firms. Given the predictions of the OECD, we predict a complementary relation between $\mathrm{CG}$ and timeliness (hypothesis stated in alternative form):

H2: The quality of the firm's CG is positively associated with timeliness of information (in documents and prices)

\subsection{Corporate Governance, and Disclosures in Good and Bad Times}

In addition to the importance of complete and timely disclosures, the TSX also identifies the need for balance in disclosures for 'good' and 'bad' news:

"Announcements of material information should be factual and balanced, neither overemphasizing favourable news nor under-emphasizing unfavourable news. Unfavorable news must be disclosed just as promptly and completely as favorable news" (TSX, 2004a, p. 5) [emphasis added].

In sum, market regulators in Canada require that, regardless of whether the news is good or bad for investors, its disclosure must be timely, complete and accessible to all market participants on the same basis. Naturally managers may wish to focus upon 'good' news and delay the release of 'bad' news for opportunistic reasons (Kothari et al., 2009; Brown et al., 
2012). An alternative view is that managers would wish to disclose impending 'bad' news on a timely basis for fear of potential litigation (Skinner, 1994) or personal reputation costs which may be incurred if non or late disclosure were subsequently discovered by market participants. We specifically examine the timeliness of documents and prices in good and bad times, and predict better-governed firms will have comparable levels of timeliness for bad and good times.

H3: For firms with better quality CG, there will be no difference in timeliness in good and bad times (for prices or documents).

\subsection{Corporate Governance and the Quality of Information from a Users' (Analysts')}

\section{Perspective}

Analysts use firm-specific disclosures in making forecasts and prior work shows the quantity of firm disclosure is positively related to analysts' earnings forecast accuracy (Hope, 2003; Vanstraelen et al., 2003). In addition, the 'quality' of these disclosures (as measured by the AIMR ratings) is important for the precision of forecasts (Byard and Shaw, 2003). Information from a variety of sources will affect analysts' expectations about future firm performance and in some instances privately generated information may substitute for public disclosures, particularly in industries with high levels of intangibles (Barth et al., 2001).

Prior literature shows CG quality is positively associated with analyst forecast accuracy (BB06; Byard et al., 2006). We examine the bias in a consensus earnings forecast (i.e. sign of earnings forecast error) which can be positive (optimistic) or negative (pessimistic) and the level of accuracy (i.e. the absolute forecast error) in those forecasts. We expect higher quality CG will lead to better quality information about future earnings performance and consequently, lower bias and greater precision in analysts' earnings forecasts. This leads to our hypotheses (stated in the alternative): 
H4: The quality of firm's CG is negatively associated with forecast bias.

H5: The quality of firm's CG is positively associated with forecast accuracy (i.e. smaller forecast errors).

We also investigate the level of dispersion (disagreement) in forecasts. The evidence to date on the impact of information quality and quantity on the dispersion in forecasts is at best inconclusive. Consensus in analyst forecasts may decline around earnings announcements as this provides analysts with incentives to generate their own information (Barron et al., 2002; Barron et al., 2005), while Lang and Lundholm (1996) show that firms with more informative disclosure policies have less dispersed analyst forecasts. Although Australian firms with higher CG have been found to have greater dispersion (disagreement) in analysts' earnings forecasts (BB06). As a result of the conflict in prior evidence, we offer no hypothesis for the level of dispersion in EPS forecasts. In addition to the precision and dispersion in forecasts, we also examine whether analyst following is associated with CG. Prior literature has shown, for example, that if there is greater information disclosure, more institutional investors and analysts may be attracted to the firm (Lang and Lundholm, 1996; Botosan, 1997; Healy et al., 1999). Also BB06 and Aman et al. (2011) found better governed firms are associated with greater analyst following. Based upon prior evidence we predict (hypothesis stated in the alternative):

H6: The quality of firm's CG is positively associated with analyst following.

\section{Sample and Data}

Our primary sample consists of firms included on the S\&P/TSX Composite Index and rated by the BSCI with year ends between 1 January 2002 and 31 December 2007. This period is specifically chosen to predate the 2008 financial crisis and is also a period when there was 
substantial variation in firm's CG structures. ${ }^{4}$ Financial and industrial sector data is collected from a variety of sources, outlined below, and yields a sample of 1,066 firm-year observations for 243 unique firms for the documents and timeliness sample, and 7,127 firmmonth observations for 165 unique firms for the analysts' sample. ${ }^{5}$

\subsection{Measuring Corporate Governance Quality}

We use the 2003 to 2008 annual BSCI reports to measure CG. ${ }^{6}$ This detailed dataset rates firms on several aspects of CG: (i) Director independence (Independence), (ii) Directors' stock ownership (Stock Ownership), (iii) Board and committee structure and share voting rights (Structure), (iv) Individual director's and full board performance evaluation systems (System); and (v) Board decision output (Output). There is also an overall measure of CG (Total). ${ }^{7}$ For measures (i) to (v), each company is ranked from AAA to C, whereby AAA represents highest-quality CG structures and $\mathrm{C}$ represents the other extreme. (For the overall measure, Total, the highest ranking is AAA+ rather than AAA). Each aspect is also given a numerical score (out of 100) and deductions are made for inferior quality CG. This creates a non-linear scale increasing in CG quality. Further details on the specific CG measures are provided below:

\footnotetext{
${ }^{4}$ A study of Canadian firms in 2006 found fewer than 7 per cent of companies in the sample were fully compliant with best practice for CG, suggesting considerable diversity in practices across firms at the time of our study (Luo and Salterio, 2014).

${ }^{5}$ We exclude observations from the Construction $(N=2)$ and Agriculture, Forestry and Fishing $(N=6)$ industries from the documents and timeliness sample due to the low number of observations for these industries. Our results are not sensitive to this decision. There are 164, 180,181, 188, 184, 169 firm-year observations for the years 2002 to 2007 respectively in the documents and timeliness sample. In the analysts' sample, a firm may appear up to 11 times per firm-financial year as the data is on a monthly basis. We exclude observations from the Construction industry $(N=21)$ to be consistent in industry coverage with the documents and timeliness sample. Our results are not sensitive to this decision. The observations across our sample period (by calendar year) are: $1,000,1,181,1,204,1,192,1,299$ and 1,251 for the years 2002 to 2007 respectively.

${ }^{6}$ We assume that the current year CG report relates to governance in place in the prior financial year (i.e. the BSCI 2003 report relates to the CG in place for the company's annual report in 2002) and we match data following this protocol. As in Aggarwal et al., (2011), where CG data is missing for a particular firm year, we forward and back-fill values of CG by 1 year to create a more complete panel of data for analysis. This procedure is justified by the stickiness in CG measures (Brown et al., 2011).

${ }^{7}$ Further details of measurement of CG, see https://www.rotman.utoronto.ca/FacultyAndResearch/ResearchCentres/ClarksonCentreforBoardEffectiveness/B oardShareholderConfidenceIndex.aspx .
} 
Director Independence (Independence) evaluates the relationships between directors and management (i.e. whether they are affiliated with management), and the relationships between individual directors through board interlocks. CG best practice (discussed in section 2.2) suggests a firm's board of directors should comprise a majority of independent members. The existence of independent directors should increase monitoring of managers (Fama and Jensen, 1983; OECD, 2004) and reduce the likelihood of fraud (Beasley, 1996), whilst also improving overall firm transparency. Independence also includes a measure of how many directorships each individual director holds. Core et al., (1999) provide evidence that multiple directorships can impact on a director's ability to carry out their duties effectively. This could mean less effective monitoring may take place if directors hold 'too many' directorships. Deductions are made if the board is not at least two thirds independent, if more than one board interlock exists and also if board members hold more than five board memberships at the same time.

Directors' Ownership (Stock Ownership) evaluates the share ownership of directors (for the third of the board with the lowest ownership) relative to the size of their annual retainer, with lower scores being awarded if the multiple is less than four times. Agency Theory predicts that greater managerial share ownership aligns managers' incentives with those of shareholders (Hart, 1995).

Board and Committee Structure (Structure) examines the structure of the board of directors and board committees. The separation of decision control and decision management is advocated by Fama and Jensen (1983) as a means to reduce agency problems. Indeed prior research demonstrates that the existence of duality (i.e. roles of CEO and Chairman of the board are taken by the same person) results in lower board independence and poor decision making (Goyal and Park, 2002; Bliss, 2011). Klein (2002) finds evidence to suggest the independence of board committees is crucial in monitoring the board of directors. Under the 
best practice recommendations (see section 2.2) there should be an independent chair or lead independent director, along with fully independent board committees. Deductions are made if there is duality and also if the principal board committees (audit and compensation) are not fully independent. Also the existence of dual class structure (i.e. difference between voting and ownership rights) on shares is also considered. The differential between voting and ownership rights (a common feature in family owned firms in Canada, Ben-Amar and André, 2006) could detrimentally affect the rights of minority shareholders (OECD, 2004). Deductions are made if the voting rights are disproportionate to the level of ownership rights, based upon the percentage of votes attached to equity.

Board Evaluation Process and Director Compensation (Systems) is concerned with the presence of performance evaluation of the board of directors' and of individual directors. The regular assessment of performance is part of the best practice recommendations (see section 2.2). Deductions are made if such systems are not in place.

Board Decision Output (Output) examines the quantity of share options granted (with a view to determining whether there has been a significant dilution in share capital), whether there has been any re-pricing of options. In addition, the level of CEO compensation relative to share price performance is also assessed. Deductions from a firm's score are made if there is significant dilution of shares following the grant of options, re-pricing of options, pay increases following a significant decline in share price, loans to directors and executives and pensions to directors as these are deemed not to be in shareholders' best interests.

\subsection{Other Data Sources}


Data for the number of documents released is hand collected from the System for Electronic Document Analysis and Retrieval (SEDAR) ${ }^{8}$. This is comparable to measures used in BB06 and Beekes et al., (2015; 2016). We source daily share prices, number of shares, returns and market index data are from Datastream. The date of the annual earnings announcement is sourced from Bloomberg, Compustat, Institutional Brokers' Estimate System (I/B/E/S), Reuters and Worldscope. ${ }^{9}$ Firm-level accounting items and industrial sector data is obtained from Worldscope. Data for analyst EPS forecasts and following is taken from $\mathrm{I} / \mathrm{B} / \mathrm{E} / \mathrm{S}$ : we collect from $\mathrm{I} / \mathrm{B} / \mathrm{E} / \mathrm{S}$ monthly forecasts for annual EPS where at least 4 analysts contribute their forecasts for a horizon of between 1 and 11 months. We use the I/B/E/S consensus forecasts to calculate our measures of forecast properties. Firms traded on the Canadian option market are sourced from the Montreal stock exchange website. Information on cross listing is collected from the Bank of New York, US exchanges and the Securities and Exchange Commission websites.

\section{Method}

\subsection{Frequency of Disclosure and Timeliness of Price Discovery}

The model in equation (1) below examines whether a firm's disclosure frequency (or timeliness) differs according to its CG, plus a set of variables which may affect information flows:

\footnotetext{
${ }^{8}$ Mandatory corporate filings in the form of press releases, annual reports and financial statements are released via SEDAR in accordance with National Instrument 13-101. Therefore this could imply price sensitivity, as determined by Canadian securities authorities. BB06 focused on documents classified by the Australian Stock Exchange as price sensitive. However, they reported their results were not sensitive to the inclusion of both price and non-price sensitive documents in their models. Thus, the fact that some releases on SEDAR would not be price sensitive should be less concern. In sensitivity analysis we use a return-weighted version of the timeliness of documents to address this issue and our results are unchanged.

${ }^{9}$ We require the release date to be greater than 14 days but less than 180 days from the financial year end date to help ensure data integrity. Where we have more than one source of data for the annual earnings release date for a particular firm year, we take the earliest plausible date.
} 


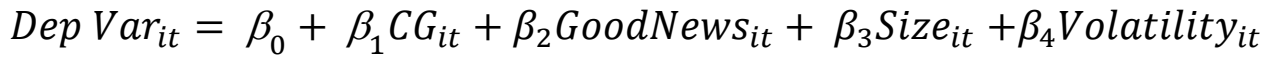

$$
\begin{aligned}
& +\beta_{5} L e v_{i t}+\gamma_{j}+\lambda_{t}+\varepsilon_{i t}
\end{aligned}
$$

where:

Dep Var is a measure of document count or timeliness (described in detail below); CG is a measure of Corporate Governance as described in section 3.1; Good News is a dummy variable which takes the value of one when the company's share price outperforms the market over the year and zero otherwise; Size is the natural log of market value at the yearend; Volatility is the volatility in daily stock returns over the 90 days before the year's start; Lev is the firm's year-end leverage measured as total debt to total assets at the yearend; $\lambda_{t}$ is a vector of year indicator variables; $\gamma_{j}$ is a vector of industry indicator variables; and $\varepsilon$ is the error term. $i$ indexes the firm and $t$ indexes the year.

The primary coefficient of interest in eq. (1) is $\beta_{1}(C G)$. If better-governed firms release more information to the share market, we would expect $\beta_{1}$ to be positive. Timeliness is reverse coded in our study such that a negative sign implies more timely prices (i.e. there is less time taken to reflect information in prices) or documents (i.e. they are released more quickly). Therefore if firms with better CG have more timely price discovery or more timely documents, we would expect $\beta_{1}$ to be negative.

\subsubsection{Dependent Variables}

The dependent variables focus on disclosures from the firm, the timeliness of disclosures and the transparency of information flows, as proxied by the timeliness of price discovery. Our measure of document count (Ldocs) is the natural log of the number of documents released by the firm to SEDAR over the year ending on its annual earnings announcement date, denoted day 0, as in BB06 and Beekes et al., (2015). We use the metric developed by BB06 to examine the timeliness of price discovery. The release of the annual earnings is an important value relevant event for all firms and timeliness $(T)$ tracks how long it takes a 
firm's share price to reach the value achieved on the annual earnings announcement date plus 14 days to enable price to settle, denoted day 0 . Timeliness therefore traces the firm's share price over 365 days ending 14 days after the firm's annual earnings announcement. Specifically, timeliness $(T)$ is defined as:

$$
T=\left(\left(\sum_{t=-365}^{t=-1}\left|\log \left(P_{0}\right)-\log \left(P_{t}\right)\right|\right)-0.5\right) / 365
$$

where $P_{t}$ is the daily market adjusted share price and the constant $-0.5 / 365$ is an adjustment to recognise the flow of information is reflected in returns over the day; ${ }^{10}$ day 0 is 14 days after the annual earnings announcement date.

The metric essentially measures how quickly the stock price reaches its terminal value (i.e. price on day 0 ); firms which take less time to adjust would have a timeliness value near to 0 (i.e. smaller values of timeliness are associated with more timely price discovery). At the individual firm level the metric could be influenced by idiosyncratic share return volatility and to acknowledge this we use a measure of timeliness which is deflated by one plus the absolute rate of return on the share over period used to calculate the share's timeliness measure, denoted Timeliness Deflated (Tdef). However, if companies release more timely information, the metric should capture this feature, insofar as it feeds into stock prices (BB06).

Following Beekes and Brown (2007); Beekes et al., (2016) we include measures that incorporate how quickly firms release documents to the stock exchange, and the timeliness of prices in good and bad times. First, we measure how quickly firms release documents to the stock exchange, i.e. the timeliness of documents (Tdocs). To do this, the number of documents released each day is cumulated in a daily time series and Tdocs is calculated as in

\footnotetext{
${ }^{10}$ If daily $\log$ returns were i.i.d. (independently and identically distributed), timeliness $(T)$ would have an expected value of 0.5 .
} 
Eq. (3). Firms which are more timely (i.e. get documents out sooner) have smaller values of Tdocs:

$$
\text { Tdocs }=\left(\left(\sum_{t=-365}^{t=-1}\left(C D_{0}-C D_{t}\right) / C D_{0}\right)-0.5\right) / 365
$$

To measure the timeliness of good news in prices (Tgood), we first identify the third quartile of the absolute value of the share's raw (unadjusted) daily log returns, $r_{t}$, observed within the timeliness "window"; call the third quartile value $Q_{3}$. We then create a market-adjusted daily $\log$ return series, $\left(\mathrm{r}_{t}^{*}, t=s, \ldots, 0\right)$, where $s$ is the starting day of the series (when timeliness is calculated from returns, $s=-364$ for the annual timeliness measure and ends on day $t=0$, as described earlier). Next we construct a time series of cumulative good news returns, $C_{t}^{G}$, by setting $C_{-365}^{G}=0$ and cumulating the daily market-adjusted $\log$ return series $C_{t}^{G}=C_{t-1}^{G}+\mathrm{r}_{t}^{G}$ from day -364 to day 0 , where $\mathrm{r}_{t}^{G}=\mathrm{r}_{t}^{*}$ if $\left|r_{t}\right|>Q_{3}$; otherwise $\mathrm{r}_{t}^{G}=0$. The timeliness of good news in prices (Tgood) is then calculated as in Eq. (4), which corresponds to Eq. (2) and Eq. (3):

$$
\operatorname{Tgood}=\left(\left(\sum_{t=-365}^{t=-1}\left(C_{0}^{G}-C_{t}^{G}\right) / C_{0}^{G}\right)-0.5\right) / 365
$$

The absolute value of the raw (unadjusted) return is used to filter the daily returns in order to mitigate undue noise due to bid-ask bounce and to allow for the fact that more than 2 in 7 prices are forward-filled (because calendar time includes non-trading days such as weekends and public holidays.) We chose the third quartile as the filter based on inspection of the empirical distributions of $\log$ returns for an ad hoc sample of about 100 firm-years. The equivalent procedure is adopted for bad news (Tbad). The all news measure (Tall) is the weighted sum of the good and bad news measures, where the weights sum to one and are $\left(C_{0}^{G} /\left[C_{0}^{G}+C_{0}^{B}\right]\right)$ and $\left(C_{0}^{B} /\left[C_{0}^{G}+C_{0}^{B}\right]\right)$ respectively and $C_{t}^{G}$ and $C_{t}^{B}$ are the unsigned good and bad news cumulative values at the end of day 0 .

\subsubsection{Explanatory Variables}


The additional firm-level variables in Eq. (1) control for other factors which could influence firm disclosure or timeliness. We control for firms with good news as they may be more likely to release information (Lev and Penman, 1990), and firm size (Size) since larger firms report more frequently than their smaller counterparts (Dye, 2001; Lang and Lundholm, 1993). In addition we control for stock volatility (Volatility) and leverage (Lev) since firms that are more risky because of their more volatile performance or high leverage, may have greater disclosures to keep market participants informed.

\subsection{The Properties of Analyst Earnings Forecasts and Analyst Following}

The models in Eqs. 5a to 5c below (based upon BB06) examine the quality of information from the analysts' perspective; i.e. whether CG provides higher quality information which impacts on the properties of analyst forecasts. We examine the bias (i.e. sign of forecast error), accuracy (i.e. the absolute forecast error) and the level of dispersion (Disagreement) in EPS forecasts. We also examine whether analysts are more likely to track firms with better CG.

$$
\begin{aligned}
\text { Bias }_{i t} & =\beta_{0}^{a}+\beta_{1}^{a} C G_{i t}+\beta_{2}^{a} \text { Following }_{i t}+\beta_{3}^{a} \text { Disagreement }_{i t}+\beta_{4}^{a} \text { Size }_{i t} \\
& +\beta_{5}^{a} \text { PrevFE }_{i t}+\beta_{6}^{a} \text { Volatility }_{i t}+\beta_{7}^{a} \text { Horizon }_{i t}+\beta_{8}^{a} \text { Option }_{i t}+\gamma_{j}+\lambda_{t}+\varepsilon_{i t}
\end{aligned}
$$

$$
\begin{aligned}
& \text { Accuracy }_{i t}=\beta_{0}^{b}+\beta_{1}^{b} C G_{i t}+\beta_{2}^{b} \text { Following }_{i t}+\beta_{3}^{b} \text { Disagreement }_{i t}+\beta_{4}^{b} \text { Size }_{i t} \\
& \quad+\beta_{5}^{b} \text { ABS }(\text { PrevFE })_{i t}+\beta_{6}^{b} \text { Volatility }_{i t}+\beta_{7}^{b} \text { Horizon }_{i t}+\beta_{8}^{b} \text { Option }_{i t}+\gamma_{j}+\lambda_{t}+\varepsilon_{i t}
\end{aligned}
$$

$$
\begin{aligned}
& \text { Disagreement }_{i t}=\beta_{0}^{c}+\beta_{1}^{c} C G_{i t}+\beta_{2}^{c} \text { Following }_{i t}+\beta_{3}^{c} \text { Size }_{i t} \\
& \quad+\beta_{4}^{c} \text { ABS }(\text { PrevFE })_{i t}+\beta_{5}^{c} \text { Volatility }_{i t}+\beta_{6}^{c} \text { Horizon }_{i t}+\beta_{7}^{c} \text { Option }_{i t}+\gamma_{j}+\lambda_{t}+\varepsilon_{i t}
\end{aligned}
$$

$$
\begin{gathered}
\text { Following }_{i t}=\beta_{0}^{d}+\beta_{1}^{d} C G_{i t}+\beta_{2}^{d} \text { Size }_{i t}+\beta_{3}^{d} A B S(\text { PrevFE })_{i t}+\beta_{4}^{d} \text { Volatility }_{i t} \\
+\beta_{5}^{d} \text { Horizon }+\beta_{6}^{d} \text { Option }+\gamma_{j}+\lambda_{t}+\varepsilon_{i t}
\end{gathered}
$$


where:

Bias is the signed Forecast Error (FE). FE is defined as the mean forecast EPS less EPS as reported by $\mathrm{I} / \mathrm{B} / \mathrm{E} / \mathrm{S}$, deflated by the base share price (i.e. share price a year before the announcement month); Accuracy is the absolute value of the FE, deflated by the base price; Disagreement is the level of disagreement in forecasts measured by the standard deviation across analysts' EPS forecasts for that firm-month, deflated by the base price; Following is the natural log of the number of analysts contributing to the consensus EPS forecast; Size is firm size proxied by the natural log of the firm's total assets at the year-end; PrevFE is the prior year FE for the same firm and same forecast horizon, deflated by the previous year's base price; ABSPrevFE is the absolute value of PrevFE, deflated by the previous year's base price; Volatility is calculated from daily returns in the 90 days ended the day before the $\mathrm{I} / \mathrm{B} / \mathrm{E} / \mathrm{S}$ forecast date; Option is a dummy variable coded 1 for firms with exchange-traded options, and 0 otherwise; Horizon is the forecast horizon, measured by the number of months from the forecast date until the company makes its annual earnings announcement to the TSX; and CG is as previously defined.

\subsubsection{Explanatory variables}

We control for firm size (Size) as analysts tend to make more accurate forecasts and disagree less often about the future earnings of larger companies. In addition, larger firms generally attract a greater analyst following (Bhushan, 1989). We control for the previous year's forecast error over the same forecast horizon (PrevFE) in the Bias model and its absolute value $(A B S[$ PrevFE $])$ in the accuracy, disagreement and following models as prior year forecasting 'success' or otherwise may influence this year's forecasts (Michail et al., 1997). Our models also control for firms which have more volatile performance proxied by return volatility (Volatility) as it is more challenging to make future earnings predictions for such firms. In addition, we control for the length of the forecast horizon i.e. length of time in 
months until the earnings announcement (Horizon) as forecasts tend to improve nearer to the date of the earnings release because of the progressive release of information throughout the year. We also control for firms traded on the options market (Option), which can provide incentives for analysts to uncover news about a particular firm (BB06).

We include Following and Disagreement in the Bias and Accuracy models as they could indicate circumstances that reduce the level of bias and increase accuracy in forecasting. We also control for Following in the Disagreement model as greater analyst following could result in more consistent forecasts. However, it must be acknowledged that even when presented with the same disclosures, analysts may weight or interpret the information differently or generate additional private information, potentially resulting in greater divergence in beliefs (Barron et al., 2005; Kandel and Pearson, 1995; Bamber et al., 1999). Therefore it is entirely possible to have greater optimistic or pessimistic bias and less accuracy in forecasting, accompanied by increased disagreement in forecasts where there is greater analyst following.

Following our hypotheses, we expect $\beta_{1}(C G)$ to have a negative value in the Bias and Accuracy models and $\beta_{1}$ to have a positive value in the analyst Following model. We have no prediction for the sign of the coefficient on $C G$ in the Disagreement model.

\section{Results}

\subsection{Descriptive Statistics}

Descriptive statistics for variables in the frequency of disclosure and timeliness models are presented in Table 1, panel A. Companies in the sample released between 5 and 338 documents per year, with a mean of 82 documents, which is roughly 2 documents per week on average (Docs). Recall smaller values of timeliness mean more timely document release 
and price discovery. The timeliness of documents (Tdocs) ranges from 0.21 to 0.68 with an average of 0.44. Timeliness, $T$, (Timeliness Deflated, Tdef) ranges from $0.02(0.02)$ to 2.11 (0.67), with an average of 0.19 (0.13). The timeliness of good, bad and all news (Tgood, Tbad and Tall, respectively) have similar distributions and averages of around 0.5. Although some firms score well on individual aspects of CG (Independence, Stock Ownership, Structure, Systems and Output), there is still considerable variation in scores for individual elements of CG across our sample of Canadian firms. The overall measure of CG (Total) has a mean of 62 (i.e. a B grade on the BSCI rating), suggesting average CG was not particularly high during our sample period. The Services and Wholesale Trade sectors have the greatest CG quality $($ Total mean $=71)$ and Mining has the lowest quality CG $($ Total mean $=56)$, not tabulated.

\section{TABLE 1 XX}

Table 1 panel B presents the descriptive statistics for the analyst sample. There is a small optimistic bias in analyst forecasts relative to actual EPS, with the mean Bias being about 0.3 per cent of the base share price. The absolute value of the forecast error (Accuracy) was on average 1.4 per cent of the base price. On average 9 analysts contributed to the $\mathrm{I} / \mathrm{B} / \mathrm{E} / \mathrm{S}$ consensus forecast. The mean value for Total is 65 (a B rating). The highest mean aggregate CG quality is in the Wholesale Trade sector (Total mean $=80)$ and the lowest is in Retail Trade $($ Total mean $=60)$, results not tabulated.

\section{TABLE 2 XX}

Table 2, panel A shows the variable correlations for the frequency of disclosure and timeliness models. The number of documents released (Ldocs) is positively related with CG (Total) and firm size (Size). The individual components of CG are positively correlated with each other, although individual correlations are relatively low between CG measures 
providing some reassurance that they capture different aspects of CG. Structure and Systems are significantly positively correlated with Ldocs. All measures of CG are negatively correlated with $T$ and Tdef, suggesting more timely price discovery for firms with better $C G$, consistent with H2. Variable correlations for the analyst sample are shown in Table 2, panel B. Bias and Accuracy are positively correlated $(r=0.40)$. In addition, while Total is negatively correlated with Bias, Accuracy and Disagreement, it is positively correlated with Following. Individual components of CG, where significant, correlate in the same direction as Total for Bias, Accuracy, Disagreement and Following.

\subsection{Multivariate Results}

Table 3 shows the results from models estimating the relationship between CG, disclosure and timeliness. The models are estimated by pooled Ordinary Least Squares (OLS) regression methods with standard errors clustered by firm to control for heteroskedasticity and within firm correlation in the residuals. Also all models control for year and industry fixed effects, but their estimated coefficients are omitted from the tables in the interests of brevity. The coefficients reported in tables are standardised to assist interpretation. ${ }^{11}$

\section{TABLE 3 XX}

The results using the composite measure of CG (Total) are shown in columns (1) to (4) of Table 3. Consistent with BB06, better-governed firms are associated with greater disclosure (ldocs) and more timely price discovery (Tdef). Results for timeliness $(T)$ are comparable to those for Tdef and are not tabulated in the interests of brevity. We also find better-governed

\footnotetext{
${ }^{11}$ The standardisation process is as follows: for continuous variables we subtract the mean and divide by the standard deviation; for indicator variables we subtract the mean; for interaction variables we subtract the mean of the variable created by the interaction of the indicator variable and the standardized continuous variable. The transformations are based on the means and standard deviations of the sub-sample of cases used to fit the particular model. The mean-centring of right hand side variables causes the constant term to be the mean of the dependent variable, so that marginal effects (as reflected in the size of the coefficients) are readily interpreted relative to the average value of the dependent variable. The advantage of this process is that it removes the arbitrary scale of the continuous independent variables and allows easier identification of variables with greater influence on the dependent variable.
} 
firms are associated with less timely release of documents to the market (Tdocs). In this study we are specifically interested in which components of CG are influential and the results are shown in columns (5) to (8) of Table 3. In column (5), Structure is positive and significant, indicating boards with more independent representation release more documents, consistent with H1. However, boards with greater directors' Stock Ownership are associated with fewer disclosures to the market. This perhaps indicates incentives to retain information within the organisation for opportunistic reasons where managers have high levels of ownership.

With regard to the timeliness of documents (Tdocs) Structure and Output are associated with less timely document releases (column 6). This is contrary to $\mathrm{H} 2$, but may suggest a more cautious and balanced approach to disclosures. In order to assess the relative importance of disclosures made to the market, we weight each day on which at least one document was released by the return on that day and construct return-weighted measures of Tdocs ${ }^{12}$ Results (not tabulated) are comparable to those for the unweighted measure. The results for timeliness deflated, Tdef, (column 7) show Stock Ownership is associated with less timely price discovery, whereas Independence and Output are associated with more timely price discovery. Systems and Stock Ownership are associated with less timely price discovery for the timeliness of all news, Tall (column 5). Our control variables are generally of the expected sign.

Given the TSX's assumption of equal treatment for favourable and unfavourable news disclosures, we investigate disclosure and timeliness in 'bad' and 'good' times. Our results are shown in Table 4. Using Total as our measure of CG, we find better-governed firms are associated with less timely document release and less timely price discovery in good times,

\footnotetext{
${ }^{12}$ To implement this procedure, all document release dates that are non-trading days are "bumped forward" to the first trading day after that release date. Then, to allow for the possibility a given release was made after the last sale for the day, we use the size of the market-adjusted log return from the close of the previous trading day until the close of the trading day after the release date as the weight, unless a further disclosure was also made on the day after. In the latter case, we use the closing price on the (possibly "bumped") release date, in order to avoid double counting of returns. (Further details are available from the corresponding author.)
} 
columns 1 and 3. This suggests monitoring provided by CG delays news release and consequently slows incorporation of news into prices inconsistent with H3. However there is no significant association found between $C G$ and the timeliness of documents or prices in bad times (columns 2 and 4).

\section{TABLE 4 XX}

Examining the components of CG, we find firms with better Structure release documents more slowly when there is good news, column 5. This is consistent with greater monitoring from independent directors causing firms to adopt a more cautious approach to the release of documents. Firms with better Output are less timely in releasing documents when there is bad news (column 6). Independence is associated with more timely prices, although better Systems are associated with less timely prices when there is good news (column 7). We find no significant association between any aspect of CG and the timeliness of bad news in prices.

In sum our results show the proportion of affiliated directors, the presence of board interlocks and the number of board memberships of individual directors (Independence) appears to have little impact on the quantity and timeliness of disclosures. Better quality board and committee Structures are associated with greater disclosure to the stock market. However, this aspect of CG also appears to delay the release of disclosures (especially when there is good news), perhaps due to the additional monitoring provided by the chairman and board committees and a desire to not over-emphasize good news. Better board decision Output is associated with less timely release of documents to the market, especially when there is bad news.

Next, we evaluate the impact of CG on the quality of information from a user's perspective. As our analyst data are monthly, models were estimated using pooled OLS regressions with standard errors clustered by firm-month to control for heteroskedasticity. All regressors are standardized as previously described. The results are shown in Table 5. 


\section{TABLE 5 XX}

We find CG is associated with greater forecast Accuracy as reflected in a negative and significant coefficient on Total (column 2), We also find evidence of less dispersion in forecasts (Disagreement) and greater analyst Following for firms with better CG, see Table 5 columns 3 and 4. This differs from results from BB06 which find Australian firms with better CG are associated with greater disagreement in EPS forecasts, although it is clear that even from the same information, analysts can make different predictions. We find no significant association between $\mathrm{CG}$ and forecast Bias. Examining the association of $\mathrm{CG}$ components and Bias, we find Structure is positive and significant, indicating analysts make more optimistic forecasts for firms with better board structures. Forecast Accuracy improves with the proportion of independent directors as Independence is negative and significant (column 6). This is perhaps because managers of firms with greater independent board representation would be considered to be more closely monitored. The level of dispersion in forecasts (i.e. Disagreement) is lower for firms with greater directors' Stock Ownership (column 7). Analysts are more likely to track firms with better CG: firms with more independent directors, better board Structure, evaluation Systems and board decision Output (column 8). The control variables are largely in line with expectations.

In sum better-governed firms are associated with better quality information, as reflected in more accurate earnings forecasts and greater consensus with respect to views on future earnings performance. In addition, better-governed firms are also associated with greater analyst following. More detailed analysis suggests the structure of the board and its committees are important for forecast accuracy. In addition, firms with greater directors' share ownership are associated with less dispersion in analyst forecasts. Also firms with better board structures, accompanied by the use of evaluation systems and better decision output are associated with greater analyst following. 


\subsection{Robustness Testing}

We subject our main results of the documents and timeliness models to a variety of robustness tests (results not tabulated): (i) using the natural log of total assets at the year-end for firm size; (ii) exclusion of firms from the mining sector from our sample as specific disclosure requirements exist for this sector (for example, National Instrument 43-101 Standards of Disclosure for Mineral Projects and the TSX guidance for mineral companies, TSX, 2004c); ${ }^{13}$ (iii) exclusion of firms from the financial sector from our sample; ${ }^{14}$ (iv) inclusion of the book to market value as an explanatory variable to control for growth opportunities, as firms with more growth opportunities may have incentives to conceal information for fear of proprietary costs (Verrecchia, 1983); (v) using an alternative score for $\mathrm{CG}$; specifically transforming the letter grade to a numeric scale, with a 6 corresponding to $\mathrm{AAA}+$ and 1 to $\mathrm{C}$ from $\mathrm{BSCI}$; (vi) winsorizing our dependent variables at the top and bottom 1 per cent to control for outliers; (vii) excluding cross-listed firms ${ }^{15}$ and (viii) using an alternative measure of CG in place of Total known as Gov 24 from Institutional Shareholder Services data. ${ }^{16}$ For the documents model, we re-estimated our results using pooled Poisson estimation methods which specifically controls for count dependent variables and our conclusions were unaffected. In the analyst models, we sequentially included additional

\footnotetext{
${ }^{13}$ The mining sector has $N=320(N=1,729)$ observations in the documents and timeliness (analyst) sample. The results from Tdocs Bad and Tgood models in Table 4 are sensitive to these changes. Bettergoverned firms are associated with significantly less timely documents when there is bad news (Total coeff. = $\left.0.008 ; t=1.99^{* * *}\right)$. However the Tgood models, Total and Independence are no longer significant, but Output is negative and significant (Output coeff. $=-0.002, t=1.89^{* *}$ ). In the analyst models, Output is positive and significant in the Bias model (Output coeff. $=0.005, t=2.15^{* * *}$ ), but loses significance in the Following model.

${ }^{14}$ The financials sector has $N=149(N=1,298)$ observations in the documents and timeliness (analyst) sample. The significance of Total in the Ldocs, Tdef and Tgood models in Tables 3 and 4 are sensitive to this change of sample. Results for individual components are weaker, although broadly consistent with those reported in the main tables.

${ }^{15}$ There are $N=669(5,054)$ observations in the documents and prices (analyst) sample which relate to firms which are not cross-listed. The significance of Total in the Tdocs and Tdocs Good models are sensitive to this change.

${ }^{16}$ Additional data requirements result in a sample comprising $N=632(4,646)$ observations for the documents and prices (analyst) sample which relate to firms with year ends from 1 January 2003 to 31 December 2007. The significance of CG in the Tdocs, Tdef, Tdocs Good is sensitive to this change. Also we find Tall is positive and significantly associated with CG (Gov24 coeff $=0.003, t=2.46^{* *}$ ), suggesting CG is associated with less timely prices for all news consistent with Beekes et al., (2016). For the analyst model, we find Gov24 is associated with analyst following only (Gov24 coeff. $=0.06, t=3.63^{* * *}$ )
} 
explanatory variables for (a) firm leverage, defined as total assets divided by total liabilities, (b) loss years, defined as an indicator variable set equal to one for loss years (i.e. when actual EPS was negative) and zero otherwise, and (c) documents released by the firm (Ldocs). ${ }^{17}$ The results are broadly consistent across the various specifications except where identified.

\subsubsection{The Impact of Cross Listing in US}

We conduct a difference of means $t$-test comparing cross-listed and non-cross-listed firms in our sample (results not tabulated). We find, on average, cross-listed firms tend to be larger (Size) and have better overall CG (Total). Also cross listed firms release a significantly higher quantity of documents (Ldocs), but these are released on a less timely basis (Tdocs) relative to other firms in the sample. We find cross-listed firms are associated with more accurate analyst forecasts and greater analyst following, as Lang et al., (2003). In addition cross-listed firms are more likely to have exchange traded options. To examine the impact of cross listing, we re-estimate our main results for the cross-listed firms in our sample (results not tabulated). The discussion focuses on the main differences from our previous reported results.

Multivariate analysis shows cross listed firms with better CG are associated with more timely price discovery: Total is negative and significant in both Tdef (Total coeff. $=-0.008, t=$ $2.33^{* * *}$ ) and Tall (Total coeff. $=-0.003, t=1.93^{* *}$ ) models. Better-governed firms are also associated with more timely prices when there is good news (Total coeff. $=-0.004, t=$ $\left.1.96^{* * *}\right)$. However, we find no significant association between Total and the frequency or timeliness of disclosures (Ldocs or Tdocs), perhaps because cross-listed firms are already associated with a high level of disclosure to meet US Stock exchange requirements (Durand and Tarca, 2005). Examining the components of CG, Independence is no longer significant in any model, and Stock Ownership is negative and significant in documents (Ldocs) model

\footnotetext{
${ }^{17}$ Inclusion of Ldocs in the analyst models reduces the sample size to $N=6,715$. Estimation of our main results on this smaller sample leaves our conclusions unchanged.
} 
only. Better board Structure is associated with less timely document releases, particularly when there is bad news. This contrasts with our main results (Table 4) where firms with better board structures have less timely releases when there is good news. Output is associated with timelier price discovery when there is good news. Therefore cross-listed firms with better CG structures appear to be less timely at releasing documents to the exchange when there is bad news, which is interesting given the higher litigation environment of the US.

For the analyst sample, there is a significant negative relation between Total and Disagreement only; in other models Total is insignificant. In the CG component models, Stock Ownership and Systems are negative and significant in the Bias model. In addition Independence and Systems are negative and significant in the Disagreement model. Analyst following is significantly associated with greater independence of the board (Independence) only; the other $\mathrm{CG}$ variables are insignificant. In sum, Independence and performance evaluation Systems are important CG characteristics in cross listed firms for the forecast precision; they are associated with lower bias, more precise forecasts and less disagreement in analysts' views about future performance.

\subsection{Endogeneity}

To take account of endogeneity in CG, we re-compute our analysis using Instrumental Variables (IV) methods. This requires us to identify instrumental variables which are contemporaneously uncorrelated with the error, but highly correlated with the regressor for which they serve as instruments (Kennedy, 2003, p.159). Selecting an appropriate instrument is not without its challenges. Although some studies have used prior year CG as an instrument for the current year $\mathrm{CG}$, this procedure may be inappropriate given the inertia or stickiness in CG structure in adjacent years (Brown et al., 2011). 
We use two instruments for individual firm's CG in our models: the average level of CG by sector excluding the observation in question for the calculation, and the average level of CG by year (and also by horizon month in the analyst models) excluding the observation in question for the calculation. These instruments provide a benchmark of CG quality which firms may strive to attain. Whilst we do not expect a direct relationship between the error term in our models and the average industry CG or the average annual $\mathrm{CG}$, we expect there are similar expectations for firms in the same industry and the same year.

The results from F-tests on excluded instruments in first stage regressions (not tabulated) have highly significant $p$-values. Our results (not tabulated) show endogeneity is an issue in some models; the Ldocs, Tdocs Bad, T Bad and Tall models have significant p-values in tests of endogeneity when Total is used. Only the Following models have significant $p$-value in tests for endogeneity. Our instruments are relatively robust from the Hansen test. The IV results are broadly comparable to those previously reported and our conclusions are unchanged.

\section{Conclusions}

We investigate the influence of CG on the flow of information to the market in Canada for S\&P/TSX Composite Index firms with year ends between 1 January 2002 and 31 December 2007. We use the Board Shareholder Confidence Index as our measure of CG. Our models examine the overall aggregate $\mathrm{CG}$ for a firm, as well as underlying aspects such as the proportion of independent directors of the board and its committees, directors' share ownership, CEO duality, voting and ownership rights of shareholders, director performance evaluation systems and the output from board decisions. We examine the quantity of disclosure from the firm and its timeliness, the timeliness of information in prices and the 
quality of information to users as proxied by accuracy, bias and agreement in market participants' (proxied by analysts') expectations of future earnings.

Consistent with BB06 we find greater disclosure and more timely price discovery for firms with better CG. We also find firms with better CG are less timely in releasing the documents to the stock exchange. However, this aggregate measure of CG masks the fact that individual CG aspects can 'pull in different directions'. Firms with better board and committee structures are found to release more information but firms with greater director share ownership release less information. Also firms with more independent directors and boards which make better decisions have more timely reflection of information relating to annual earnings performance in prices.

With regard to analyst following, we find a positive association between total CG and the number of analysts following the firm. Consequently, analysts' earnings forecasts are more accurate and there is less dispersion (i.e. lower disagreement) in them. This is contrary to results from BB06 who find greater disagreement in analysts' forecasts for better-governed firms. Individual governance aspects show more independent boards are associated with greater forecast accuracy.

We attribute the differences between our study for Canada and BB06's results for Australian companies to our more comprehensive CG data and use of more robust estimation methods. Our results are relatively robust to a number of alternative specifications and in particular, our tests indicate endogeneity of CG is not a major problem in our study. Our work contributes to a growing literature on $\mathrm{CG}$ and disclosure. Future work could investigate whether the link between information disclosures and CG translates into more favourable cost of capital. However we leave this question to future research. 


\section{References}

Aggarwal, R., Erel, I. Ferreira, M. and Matos, P., 2011. Does governance travel around the world? Evidence from institutional investors. Journal of Financial Economics, 100 (1), 154-181.

Ajinkya, B., Bhojraj, S. and Sengupta, P., 2005. The association between outside directors, institutional investors and the properties of management earnings forecasts. Journal of Accounting Research, 43 (3), 343-376.

Akerlof, G.A., 1970. The market for 'lemons': Quality uncertainty and the market mechanism. The Quarterly Journal of Economics, 84 (3), 488-500.

Aman, H., Beekes, W. and Brown, P., 2011. Corporate governance and transparency in Japan, Working paper (Universities of Kwansei Gakuin, Lancaster, New South Wales and Western Australia). Available from: http://papers.ssrn.com/sol3/papers.cfm?abstract_id=1874611 [Accessed 24 May 2016].

Bamber, L.S., Barron, O.E. and Stober, T.L., 1999. Differential interpretations and trading volume. The Journal of Financial and Quantitative Analysis, 34 (3), 369-386.

Barron, O.E., Byard, D. and Kim, O., 2002. Changes in analysts' information around earnings announcements. The Accounting Review, 77 (4), 821-846.

Barron, O.E., Harris, D.G. and Stanford, M., 2005. Evidence that investors trade on private eventperiod information around earnings announcements. The Accounting Review, 80 (2), 403421.

Barth, M., Kasznik, R. McNichols, M. 2001. Analyst coverage and intangible assets. Journal of Accounting Research, 39 (1), 1-34.

Bassett, M., Koh, P-S. and Tutticci, I., 2007. The association between employee stock option disclosures and corporate governance: Evidence from an enhanced disclosure regime. The British Accounting Review, 39 (4), 303-322.

Beasley, M.S., 1996. An empirical analysis of the relation between the board of director composition and financial statement fraud. The Accounting Review, 71 (4), 443-465.

Beekes, W. and Brown, P., 2006. Do better-governed Australian firms make more informative disclosures? Journal of Business Finance and Accounting, 33 (3-4), 422-450.

Beekes, W. and Brown, P., 2007. On the timeliness of price discovery. Available from http://papers.ssrn.com/sol3/papers.cfm?abstract_id=938982. [Accessed 24 May 2016].

Beekes, W., Brown, P. and Zhang, Q., 2015. Corporate governance and the informativeness of disclosures in Australia: A re-examination. Accounting and Finance, 55 (4), 931-963.

Beekes, W., Brown, P., Zhan, W. and Zhang, Q., 2016. Corporate governance, companies' disclosure practices, and market transparency: A cross country study. Journal of Business Finance and Accounting , 43 (3-4), 263-297.

Ben-Amar, W. and André, P., 2006. Separation of ownership from control and acquiring firm performance: The case of family ownership in Canada. Journal of Business Finance and Accounting, 33 (3-4), 517-543.

Bhushan, R., 1989. Firm characteristics and analyst following. Journal of Accounting and Economics, $11(2-3), 255-274$.

Bliss, M.A., 2011. Does CEO duality constrain board independence? Some evidence from audit pricing. Accounting and Finance, 51 (2), 361-380.

Botosan, C., 1997. Disclosure level and the cost of equity capital. The Accounting Review, 72 (3), 323-349.

Brown, N.C., Christensen T.E. and Brooke Elliott, W., 2012. The timing of quarterly 'pro forma' earnings announcements. Journal of Business Finance and Accounting, 39 (3-4), 315-359. 
Brown, P., Beekes, W. and Verhoeven, P., 2011. Corporate governance, accounting and finance: A review. Accounting and Finance, 51 (1), 96-172.

Bujaki, M. and McConomy, B.J., 2002. Corporate governance: Factors influencing voluntary disclosure by publicly traded Canadian firms. Canadian Accounting Perspectives, 1 (2), 105139.

Byard, D. and Shaw, K.W. 2003. Corporate disclosure quality and properties of analysts' information environment. Journal of Accounting, Auditing and Finance, 18 (3), 355 - 378.

Byard, D. Li, Y. and Weintrop, J., 2006. Corporate governance and the quality of financial analysts' information. Journal of Accounting and Public Policy, 25 (5), 609 - 625.

Core, J.E., Holthausen, R.W. and Larcker, D.F., 1999. Corporate governance, chief executive officer compensation and firm performance. Journal of Financial Economics, 51 (3), 371-406.

Durand, R.B. and Tarca, A., 2005. The impact of US GAAP reconciliation requirements on choice of foreign stock exchange for firms from common law and code law countries. European Accounting Review, 14 (4), 789-813.

Dye, R.A., 2001. An evaluation of 'Essays on disclosure' and the disclosure literature in accounting. Journal of Accounting and Economics, 32 (1-3), 181-235.

Ettredge, M., Johnstone, K., Stone, M. and Wang, Q., 2011. The effects of firm size, corporate governance quality, and bad news on disclosure compliance. Review of Accounting Studies, $16(4), 866-889$.

Fama, E.F. and Jensen, M.C., 1983. Separation of ownership and control. Journal of Law and Economics, 26 (2), 301-325.

Goyal, V.K. and Park, C.W., 2002. Board leadership structure and CEO turnover. Journal of Corporate Finance, 8 (1), 49-66.

Hart, O., 1995. Corporate governance: Some theory and implications. The Economic Journal, 105 (430), 678-689.

Hass, L.K., Vergauwe, S. and Zhang, Q., 2014. Corporate governance and the information environment: Evidence from Chinese stock markets. International Review of Financial Analysis, 36 (December), 106-119.

Healy, P.M., Hutton, A.P. and Palepu, K.G., 1999. Stock performance and intermediation changes surrounding sustained increases in disclosure. Contemporary Accounting Research, 16 (3), 485-520.

Hermalin, B.E. and Weisbach, M.S., 2012. Information disclosure and corporate governance, The Journal of Finance, 67 (1), 195-233.

Hope, O.K., 2003. Disclosure practices, enforcement of accounting standards and analysts' forecast accuracy: An international study. Journal of Accounting Research, 41 (2), 235-272.

International Organization of Securities Commissions, 2002. Principles for Ongoing Disclosure and Material Development Reporting by Listed Entities, IOSCO. Available from: http://www.iosco.org/library/pubdocs/pdf/IOSCOPD132.pdf [Accessed 24 May 2016].

Jensen, M.C. and Meckling, W.H., 1976. Theory of the firm: Managerial behavior, agency costs and ownership structure. Journal of Financial Economics, 3 (4) 305-360.

Kandel, E. and Pearson, N.D., 1995. Differential interpretation of public signals and trade in speculative markets. The Journal of Political Economy, 103 (4), 831-872.

Kennedy, P., 2003. A guide to econometrics. $5^{\text {th }}$ ed. Oxford: Blackwell Publishing.

Klein, A., 2002. Audit Committee, Board of Director Characteristics, and Earnings Management. Journal of Accounting and Economics, 33 (3), 375-400. 
Kothari, S.P., Shu, S. and Wysocki, P.D., 2009. Do managers withhold bad news? Journal of Accounting Research, 47 (1), 241-276.

Lang, M.H. and Lundholm, R.J., 1993. Cross-sectional determinants of analyst ratings of corporate disclosures. Journal of Accounting Research, 31 (2), 246-271.

Lang, M.H. and Lundholm, R.J., 1996. Corporate disclosure policy and analyst behavior. The Accounting Review, 71 (4), 467-492.

Lang, M.H., Lins, K.V. and Miller, D.P., 2003. ADRs, analysts, and accuracy: Does cross listing in the United States improve a firm's information environment and increase market value? Journal of Accounting Research, 41 (2), 317-345.

Larcker, D.F., Richardson, S.A. and Tuna, I., 2007. Corporate governance, accounting outcomes and organizational performance. The Accounting Review, 82 (4), 963-1008.

Lev, B. and Penman, S., 1990. Voluntary forecast disclosure, nondisclosure, and stock prices. Journal of Accounting and Research, 28 (1), 49-76.

Li, J., Mangena, M. and Pike, R., 2012. The effect of audit committee characteristics on intellectual capital disclosure. The British Accounting Review, 44 (2), 98-110.

Liu, W. 2012. Ownership, corporate governance and timeliness of price discovery: Australian evidence. Unpublished Thesis, Queensland University of Technology, Brisbane, Australia.

Lim, M. How, J. and Verhoeven, P., 2014. Corporate ownership, corporate governance reform and timeliness of earnings: Malaysian evidence. Journal or Contemporary Accounting and Economics, 10 (1), 32-45.

Luo, Y. and Salterio, 2014. Governance quality in a "comply or explain" governance disclosure regime, Corporate Governance: An International Review, 22 (6), 460-481.

Michail, M.B. Walther, B.R., Willis, R.H., 1997. Do security analysts improve their performance with experience? Journal of Accounting Research, 35 (Supplement), 131-157.

Organisation for Economic Cooperation and Development, 2004. OECD principles of corporate governance. Paris: OECD. Available from: http://www.oecd.org/corporate/oecdprinciplesofcorporategovernance.htm [Accessed 24 May 2016].

Ontario Securities Commission, 2002. National policy 51-201 disclosure standards, July 122002. Available from: http://www.osc.gov.on.ca/documents/en/SecuritiesCategory5/pol_20020712_51-201.pdf [Accessed 24 May 2016].

Ontario Securities Commission, 2004. Multilateral instrument 52-110 audit committees, Available from: http://www.osc.gov.on.ca/en/SecuritiesLaw_rule_20040116_52-110_mi.jsp [Accessed 24 May 2016].

Ontario Securities Commission, 2005a. National policy 58-201 corporate governance guidelines, April 15 2005, Available from: http://www.osc.gov.on.ca/documents/en/SecuritiesCategory5/rule_20050415_58-201_gov-practices_2.pdf [Accessed 24 May 2016].

Ontario Securities Commission, 2005b. National instrument 58-101 disclosure of corporate governance practices, June 17 2005, Available from http://www.osc.gov.on.ca/documents/en/Securities-Category5/rule_20050617_58-101_disccorp-gov-pract.pdf [Accessed 24 May 2016].

Skinner, D.J., 1994. Why firms voluntarily disclose bad news. Journal of Accounting Research, 32 (1), 38-60.

Toronto Stock Exchange (TSX), 2003. Corporate governance: A guide to good disclosure. Toronto: Toronto Stock Exchange. Available from: http://www.ecgi.org/codes/documents/tsx_gtgd.pdf. [Accessed 24 May 2016]. 
Toronto Stock Exchange, 2004a. Policy statement on Timely Disclosure. Toronto: Toronto Stock Exchange. Available http://apps.tmx.com/en/pdf/PolicyStatementOnTimelyDisclosure.pdf. [Accessed 24 May 2016].

Toronto Stock Exchange, 2004b. Toronto stock exchange company manual. Toronto : Toronto Stock Exchange.

Toronto Stock Exchange, 2004c. Disclosure standards for companies engaged in mineral exploration, development and production. Available from: http://apps.tmx.com/en/pdf/TSX_DisclosureStandardsMineralExploration.pdf. [Accessed 24 May 2016].

Toronto Stock Exchange, 2004d. Notice national policy 58-201 corporate governance guidelines and national instrument 58-101 disclosure of corporate governance practices, Form 58-101F1 and Form 58-101F2. Available from https:/www.tsx.com/resource/en/75 [Accessed 24 May 2016].

Toronto Stock Exchange, 2006. Version 1.0 TSX corporate governance: Guide to good disclosure for national instrument 58-101 disclosure of corporate governance practices (NI 58-101) and multilateral instrument 52-110 - audit committees (MI 52-110) (As of January 2006) Available from http://apps.tmx.com/en/pdf/TSXGuideToGoodDisclosure.pdf. [Accessed 24 May 2016].

Vanstraelen, A., Zarzeski, M.T. and Robb, S.W.G., 2003. Corporate non-financial disclosure Practices and financial analyst forecast ability across three European countries. Journal of International Financial Management and Accounting, 14 (3), 249-278.

Verrecchia, R.E., 1983. Discretionary disclosure. Journal of Accounting and Economics, 5, 179-194. 
Table 1: Descriptive Statistics for Firm-Level Variables

\begin{tabular}{|c|c|c|c|c|c|}
\hline \multicolumn{6}{|c|}{ Panel A: Frequency of Disclosure and Timeliness Models $(N=1,066)$} \\
\hline Variable & Mean & Std. Dev. & Median & Min. & Max. \\
\hline Column No.: & (1) & $(2)$ & (3) & (4) & $(5)$ \\
\hline Docs & 81.872 & 38.895 & 74.000 & 5.000 & 338.000 \\
\hline Ldocs & 4.300 & 0.470 & 4.304 & 1.609 & 5.823 \\
\hline Tdocs & 0.442 & 0.068 & 0.445 & 0.213 & 0.678 \\
\hline Tdocs Good & 0.442 & 0.098 & 0.443 & 0.063 & 0.742 \\
\hline Tdocs Bad & 0.443 & 0.100 & 0.446 & 0.074 & 0.836 \\
\hline$T$ & 0.189 & 0.184 & 0.135 & 0.019 & 2.111 \\
\hline Tdef & 0.132 & 0.086 & 0.112 & 0.019 & 0.665 \\
\hline Tgood & 0.504 & 0.041 & 0.504 & 0.358 & 0.631 \\
\hline Tbad & 0.506 & 0.041 & 0.504 & 0.368 & 0.663 \\
\hline Tall & 0.505 & 0.034 & 0.505 & 0.382 & 0.633 \\
\hline Independence & 96.975 & 3.320 & 97.000 & 90.000 & 100.000 \\
\hline Stock Ownership & 96.597 & 5.129 & 100.00 & 85.000 & 100.000 \\
\hline Structure & 90.760 & 9.397 & 95.000 & 75.000 & 100.000 \\
\hline Systems & 92.641 & 7.070 & 95.000 & 85.000 & 100.000 \\
\hline Output & 94.690 & 7.540 & 100.000 & 70.000 & 100.000 \\
\hline Total & 61.843 & 24.398 & 50.000 & 25.000 & 100.000 \\
\hline Size & 7.531 & 1.371 & 7.358 & 3.115 & 11.176 \\
\hline Lev & 0.202 & 0.158 & 0.188 & 0.000 & 0.771 \\
\hline Volatility & 0.019 & 0.011 & 0.016 & 0.001 & 0.139 \\
\hline Good News $=1$ & 0.481 & 0.500 & & 0 & 1 \\
\hline
\end{tabular}

Panel B: Analyst Models $(N=7,127)$

\begin{tabular}{lrrrrr} 
Variable & \multicolumn{1}{c}{ Mean } & Std. Dev. & \multicolumn{1}{c}{ Median } & \multicolumn{1}{c}{ Min. } & \multicolumn{1}{c}{ Max. } \\
\hline Bias & 0.003 & 0.035 & 0.000 & -0.370 & 0.464 \\
Accuracy & 0.014 & 0.032 & 0.005 & 0.000 & 0.464 \\
Disagreement & 0.007 & 0.011 & 0.004 & 0.000 & 0.228 \\
Following & 2.177 & 0.414 & 2.200 & 1.386 & 3.296 \\
Independence & 97.099 & 3.254 & 97.00 & 90.000 & 100.000 \\
Stock Ownership & 97.048 & 4.783 & 100.00 & 85.000 & 100.000 \\
Structure & 90.930 & 9.468 & 95.00 & 75.000 & 100.000 \\
Systems & 93.860 & 6.892 & 100.00 & 85.000 & 100.000 \\
Output & 95.714 & 6.763 & 100.00 & 70.000 & 100.000 \\
Total & 65.126 & 24.272 & 75.00 & 25.000 & 100.000 \\
Size & 7.746 & 1.645 & 7.568 & 1.493 & 11.175 \\
Lev & 0.215 & 0.164 & 0.194 & 0 & 0.647 \\
PrevFE & 0.002 & 0.027 & 0.000 & -0.370 & 0.299 \\
ABS (Prev FE) & 0.013 & 0.024 & 0.005 & 0 & 0.370 \\
Volatility & 0.015 & 0.007 & 0.014 & 0.001 & 0.094 \\
Horizon & 6.020 & 3.165 & 6.000 & 1 & 11 \\
Option =1 & 0.337 & & & 0 & 1 \\
\hline
\end{tabular}


Note: The sample is constructed from firms rated in the Board Shareholder Confidence Index with year ends between 1 January 2002 and 31 December 2007. Panels A and B show the descriptive statistics for the variables in the documents and timeliness, and analyst models, respectively. Note that the documents and timeliness dataset is on a firm-year basis and the analyst dataset is on a firm-month basis. The variables are defined as follows: Docs is the annual number of documents as retrieved from the SEDAR website. Ldocs denotes the natural logarithm $(\log )$ of Docs. Tdocs is a measure of the timeliness of documents' release to the stock market. Tdocs good and Tdocsbad are the timeliness of good and bad news documents which are additional measures of timeliness in times of good and bad news respectively where documents classified as good or bad dependent upon the return for that particular day; a share price return above the market return is classified as 'good news' and a return below the market return is classified as 'bad news'. $T$ is the timeliness metric, measured as the average daily absolute difference between the log of the market-adjusted share price that day and the $\log$ of market-adjusted share price 14 days after the release of the firm's EPS for the year. Tdef is the timeliness metric divided by one plus the absolute rate of return on the share over the period used to calculate the share's timeliness metric. Tgood and Tbad are the timeliness of good and bad news which are additional measures of timeliness in times of good and bad news respectively. Tall is the timeliness of all news which is a measure of timeliness taking both good and bad news into account. Forecast Error (FE) is defined as the mean forecast EPS less actual EPS as reported by $\mathrm{I} / \mathrm{B} / \mathrm{E} / \mathrm{S}$, and is deflated by base price (stock price one day before the $\mathrm{I} / \mathrm{B} / \mathrm{E} / \mathrm{S}$ cutoff date for forecasts made a year before the release date). Bias is the signed FE and Accuracy is its absolute value. Disagreement is the standard deviation of analysts' forecasts for that firm month, deflated by base price. Following is the natural $\log$ of the number of analysts contributing to the consensus forecast. Independence, Stock Ownership, Structure, Systems, Output and Total are measures of corporate governance (see section 3.1). Size is proxied by the log of the firm's market value at the year end. Lev is the firm's year-end leverage measured as total debt to total assets. Lev is winsorized at the top and bottom 1 per cent in the analyst sample to control for outliers. Volatility is calculated from daily log returns in the 90 days ending the day before we observe the first price for the timeliness metric for the documents and timeliness models, and 90 days ended the day before the $\mathrm{I} / \mathrm{B} / \mathrm{E} / \mathrm{S}$ forecast date in the analyst models. Good news is a dummy variable with a value of one if the market adjusted return over the 365 days ended 14 days after the release date is positive, and is zero otherwise. PrevFE is the prior year's FE is for the same firm and for the same horizon, deflated by previous year's base price. ABS(PrevFE) is the absolute value of PrevFE, deflated by previous year's base price. Horizon is the forecast horizon measured as the number of months from the forecast date until the company releases its annual earnings to the TSX. Option is a dummy variable coded 1 for firms with exchange traded options, 0 otherwise. 
Table 2: Bivariate Relationships

Panel A: Variable Correlations for Frequency of Disclosure and Timeliness Models $(N=1,066)$

\begin{tabular}{|c|c|c|c|c|c|c|c|c|c|c|c|c|c|c|c|c|c|c|c|}
\hline & $(1)$ & $(2)$ & (3) & $(4)$ & $(5)$ & $(6)$ & $(7)$ & $(8)$ & $(9)$ & $(10)$ & $(11)$ & $(12)$ & $(13)$ & (14) & $(15)$ & $(16)$ & $(17)$ & $(18)$ & (19) \\
\hline \multicolumn{20}{|l|}{ 1. Docs } \\
\hline 2. Ldocs & 0.93 & & & & & & & & & & & & & & & & & & \\
\hline 3. Tdocs & 0.17 & 0.18 & & & & & & & & & & & & & & & & & \\
\hline 4. Tdocs Good & 0.12 & 0.12 & 0.69 & & & & & & & & & & & & & & & & \\
\hline 5. Tdocs Bad & 0.14 & 0.16 & 0.67 & 0.00 & & & & & & & & & & & & & & & \\
\hline 6. $T$ & -0.02 & -0.01 & 0.10 & 0.06 & 0.05 & & & & & & & & & & & & & & \\
\hline 7. Tdef & -0.02 & -0.02 & 0.09 & 0.06 & 0.03 & 0.92 & & & & & & & & & & & & & \\
\hline 8. Tgood & -0.01 & -0.01 & -0.03 & 0.13 & -0.18 & 0.18 & 0.16 & & & & & & & & & & & & \\
\hline 9. Tbad & -0.01 & 0.02 & -0.06 & -0.17 & 0.10 & 0.08 & 0.07 & 0.38 & & & & & & & & & & & \\
\hline 10. Tall & -0.01 & 0.01 & -0.05 & -0.01 & -0.05 & 0.18 & 0.17 & 0.85 & 0.81 & & & & & & & & & & \\
\hline 11. Indep. & -0.01 & -0.01 & 0.03 & 0.04 & 0.00 & -0.06 & -0.05 & 0.00 & 0.02 & 0.01 & & & & & & & & & \\
\hline 12. Stock Own. & -0.01 & -0.03 & -0.04 & -0.02 & -0.03 & -0.05 & -0.05 & 0.07 & 0.06 & 0.09 & $\mathbf{0 . 0 7}$ & & & & & & & & \\
\hline 13. Structure & 0.12 & 0.13 & 0.05 & 0.06 & 0.00 & -0.10 & -0.10 & 0.06 & 0.02 & 0.05 & 0.30 & 0.16 & & & & & & & \\
\hline 14. Systems & 0.11 & 0.12 & -0.01 & 0.00 & 0.00 & -0.22 & -0.22 & 0.11 & 0.10 & 0.12 & 0.24 & 0.22 & 0.20 & & & & & & \\
\hline 15. Output & -0.03 & -0.05 & 0.04 & -0.01 & 0.06 & -0.19 & -0.20 & -0.07 & 0.03 & -0.03 & 0.09 & 0.07 & 0.07 & 0.09 & & & & & \\
\hline 16. Total & 0.08 & 0.08 & 0.04 & 0.03 & 0.03 & -0.21 & -0.22 & 0.05 & 0.04 & 0.06 & 0.47 & 0.40 & 0.69 & 0.56 & 0.45 & & & & \\
\hline 17. Size & 0.30 & 0.30 & -0.06 & -0.08 & 0.01 & -0.43 & -0.46 & 0.02 & 0.12 & 0.08 & -0.08 & 0.18 & 0.11 & 0.34 & 0.16 & 0.25 & & & \\
\hline 18. Lev & 0.00 & 0.01 & -0.02 & -0.04 & 0.03 & -0.10 & -0.11 & -0.03 & 0.05 & 0.01 & 0.07 & -0.04 & -0.05 & 0.11 & 0.11 & 0.05 & 0.10 & & \\
\hline 19. Volatility & 0.05 & 0.05 & 0.12 & 0.08 & 0.08 & 0.51 & 0.48 & -0.15 & -0.21 & -0.21 & -0.08 & -0.10 & -0.13 & -0.29 & -0.17 & -0.25 & -0.46 & -0.21 & \\
\hline 20. Good News & 0.04 & 0.03 & 0.04 & 0.05 & 0.01 & 0.05 & 0.05 & -0.04 & -0.09 & -0.08 & -0.06 & 0.03 & -0.03 & -0.06 & -0.03 & -0.04 & 0.00 & -0.04 & 0.12 \\
\hline
\end{tabular}


Panel B: Variable Correlations for Analyst Models $(N=7,127)$

\begin{tabular}{|c|c|c|c|c|c|c|c|c|c|c|c|c|c|c|c|c|}
\hline & (1) & $(2)$ & $(3)$ & (4) & $(5)$ & $(6)$ & $(7)$ & $(8)$ & $(9)$ & $(10)$ & (11) & $(12)$ & (13) & (14) & $(15)$ & $(16)$ \\
\hline 1. Bias & & & & & & & & & & & & & & & & \\
\hline 2. Accuracy & 0.40 & & & & & & & & & & & & & & & \\
\hline 3. Disagreement & 0.09 & 0.37 & & & & & & & & & & & & & & \\
\hline 4. Following & -0.03 & -0.06 & 0.02 & & & & & & & & & & & & & \\
\hline 5. Independence & -0.02 & -0.07 & -0.02 & 0.06 & & & & & & & & & & & & \\
\hline 6. Stock Own. & -0.04 & -0.09 & -0.13 & 0.15 & 0.10 & & & & & & & & & & & \\
\hline 7. Structure & 0.00 & -0.07 & -0.02 & 0.14 & 0.23 & 0.22 & & & & & & & & & & \\
\hline 8. Systems & -0.07 & -0.03 & -0.07 & 0.22 & 0.18 & 0.25 & 0.20 & & & & & & & & & \\
\hline 9. Output & 0.00 & -0.12 & -0.12 & 0.11 & 0.10 & 0.08 & 0.03 & $\mathbf{0 . 0 7}$ & & & & & & & & \\
\hline 10. Total & -0.06 & -0.13 & -0.12 & 0.22 & 0.42 & 0.45 & 0.72 & 0.54 & 0.43 & & & & & & & \\
\hline 11. Size & -0.08 & -0.13 & -0.15 & 0.36 & -0.16 & 0.08 & 0.09 & 0.21 & 0.09 & 0.14 & & & & & & \\
\hline 12. Lev & 0.04 & 0.04 & 0.04 & 0.09 & 0.08 & -0.02 & -0.09 & 0.08 & $\mathbf{0 . 0 7}$ & 0.01 & 0.04 & & & & & \\
\hline 13. PrevFE & -0.02 & 0.11 & 0.20 & -0.02 & 0.04 & -0.05 & 0.00 & -0.03 & -0.03 & -0.03 & -0.11 & 0.06 & & & & \\
\hline 14. ABS(PrevFE) & 0.06 & 0.30 & 0.41 & -0.07 & 0.05 & -0.07 & -0.02 & -0.04 & -0.06 & -0.05 & -0.17 & 0.02 & 0.19 & & & \\
\hline 15. Volatility & 0.08 & 0.16 & 0.26 & -0.10 & -0.01 & -0.10 & -0.11 & -0.18 & -0.14 & -0.19 & -0.30 & -0.08 & 0.06 & 0.21 & & \\
\hline 16. Horizon & 0.03 & 0.17 & 0.09 & 0.04 & 0.00 & 0.00 & 0.00 & 0.01 & 0.00 & 0.00 & 0.00 & 0.00 & 0.04 & 0.22 & -0.04 & \\
\hline 17. Option & -0.07 & -0.06 & -0.04 & 0.45 & -0.06 & 0.18 & 0.14 & 0.22 & -0.03 & 0.17 & 0.53 & 0.05 & -0.08 & -0.09 & -0.17 & -0.03 \\
\hline
\end{tabular}

Notes: Variables as defined in Table 1. Bold text indicates significant correlation at 5 per cent or better. 
Table 3: The Relationship Between Aspects of Corporate Governance, Disclosure and Timeliness $(N=1,066)$

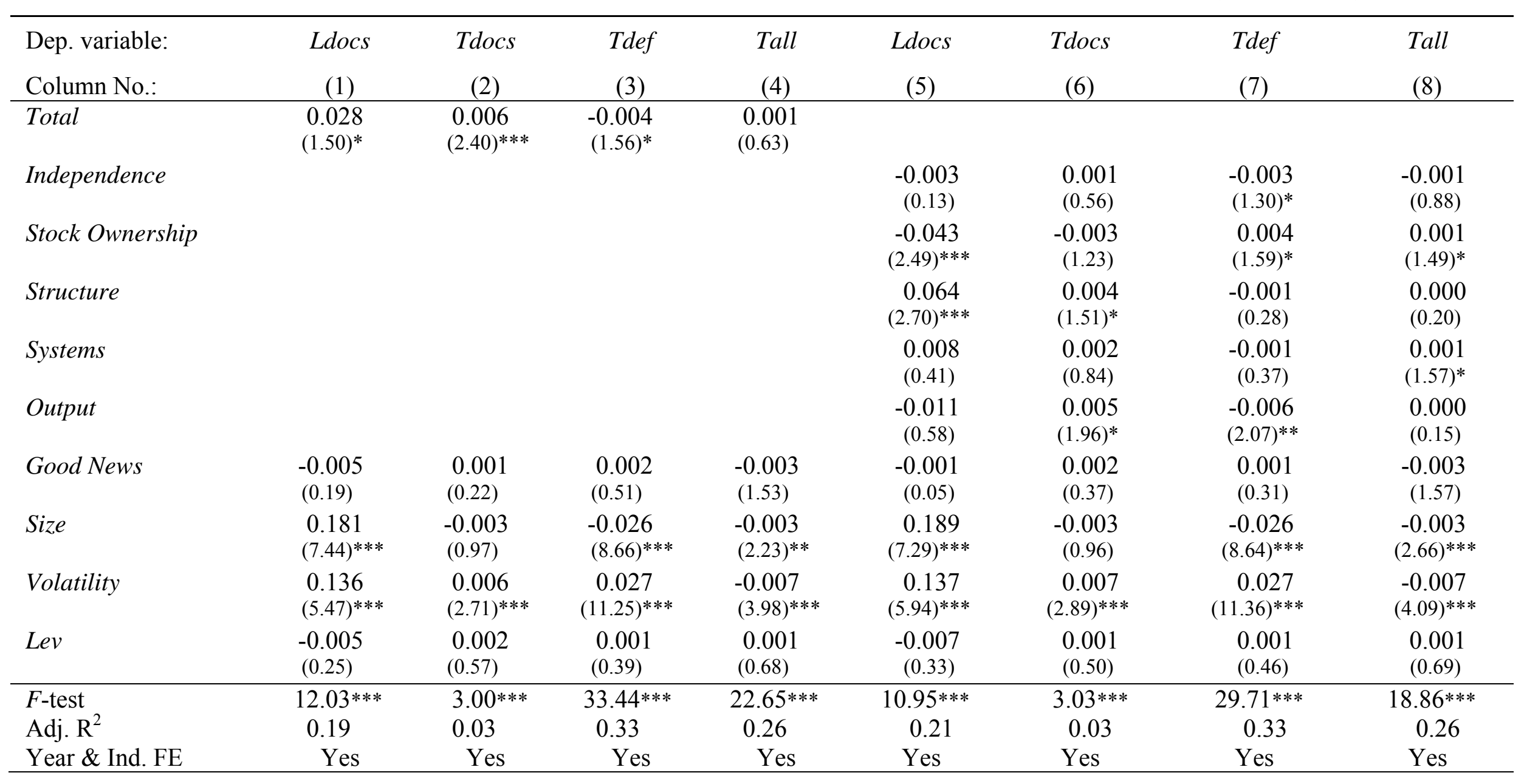

Note: All coefficients relate to variables that have been standardized to assist interpretation. The sample comprises firms rated in the Board Shareholder Confidence Index with year ends between 1 January 2002 and 31 December 2007. Results are estimated using pooled Ordinary Least Squares methods with robust standard errors clustered by firm to control for heteroskedasticity. See Table 1 for variable definitions. $t$-statistics with standard errors clustered by firms in parentheses. $* p<0.1 ; * * p<0.05 ; * * * p<0.01$ (one-tailed $t$-tests for hypothesised effects and two-tailed $t$-tests for control variables) 
Table 4: The Relationship Between Corporate Governance, Disclosure and Timeliness in Good and Bad Times $(N=1,066)$

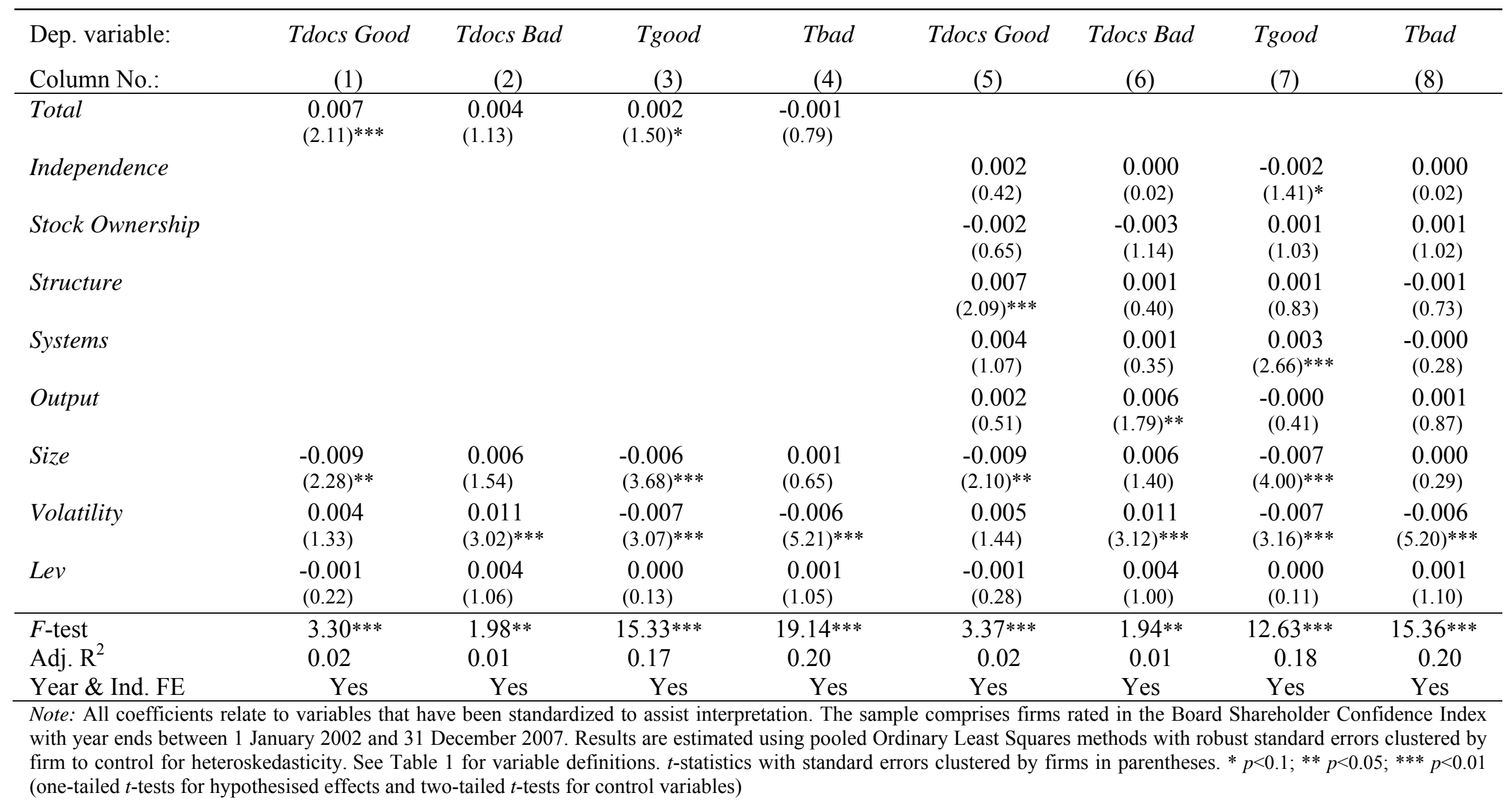


Table 5: The Relationship Between Corporate Governance and Properties of Analysts’ Forecasts, and Analyst Following ( $N=7,127)$

\begin{tabular}{|c|c|c|c|c|c|c|c|c|}
\hline $\begin{array}{l}\text { Dep.Variable: } \\
\text { Column No.: }\end{array}$ & $\begin{array}{r}\text { Bias } \\
(1) \\
\end{array}$ & $\begin{array}{c}\text { Accuracy } \\
(2)\end{array}$ & $\begin{array}{c}\text { Disagreement } \\
(3)\end{array}$ & $\begin{array}{c}\text { Following } \\
(4)\end{array}$ & $\begin{array}{r}\text { Bias } \\
(5) \\
\end{array}$ & $\begin{array}{c}\text { Accuracy } \\
(6)\end{array}$ & $\begin{array}{c}\text { Disagreement } \\
(7)\end{array}$ & $\begin{array}{c}\text { Following } \\
(8)\end{array}$ \\
\hline Total & $\begin{array}{l}-0.001 \\
(0.66)\end{array}$ & $\begin{array}{l}-0.002 \\
(2.51)^{* * *}\end{array}$ & $\begin{array}{l}-0.001 \\
(2.48)^{* *}\end{array}$ & $\begin{array}{l}0.066 \\
(5.10)^{* * *}\end{array}$ & & & & \\
\hline Independence & & & & & $\begin{array}{c}-0.001 \\
(0.60)\end{array}$ & $\begin{array}{l}-0.002 \\
(1.63)^{*}\end{array}$ & $\begin{array}{c}-0.000 \\
(0.95)\end{array}$ & $\begin{array}{c}0.021 \\
(1.62)^{*}\end{array}$ \\
\hline Stock Ownership & & & & & $\begin{array}{c}-0.001 \\
(0.53)\end{array}$ & $\begin{array}{c}-0.001 \\
(1.11)\end{array}$ & $\begin{array}{l}-0.001 \\
(3.81)^{* * *}\end{array}$ & $\begin{array}{l}0.015 \\
(1.11)\end{array}$ \\
\hline Structure & & & & & $\begin{array}{c}0.001 \\
(1.38)^{*}\end{array}$ & $\begin{array}{c}-0.001 \\
(1.01)\end{array}$ & $\begin{array}{l}0.000 \\
(1.24)\end{array}$ & $\begin{array}{c}0.027 \\
(2.22)^{* * *}\end{array}$ \\
\hline Systems & & & & & $\begin{array}{c}-0.002 \\
(1.11)\end{array}$ & $\begin{array}{l}0.002 \\
(1.28)\end{array}$ & $\begin{array}{l}0.000 \\
(1.03)\end{array}$ & $\begin{array}{c}0.041 \\
(3.00)^{* * *}\end{array}$ \\
\hline Output & & & & & $\begin{array}{l}0.002 \\
(0.74)\end{array}$ & $\begin{array}{c}-0.002 \\
(0.92)\end{array}$ & $\begin{array}{c}-0.001 \\
(1.31)\end{array}$ & $\begin{array}{c}0.033 \\
(2.49)^{* * *}\end{array}$ \\
\hline Following & $\begin{array}{l}0.001 \\
(0.81)\end{array}$ & $\begin{array}{l}-0.001 \\
(0.83)\end{array}$ & $\begin{array}{c}0.001 \\
(1.87)^{*}\end{array}$ & & $\begin{array}{l}0.001 \\
(0.70)\end{array}$ & $\begin{array}{c}-0.001 \\
(0.79)\end{array}$ & $\begin{array}{c}0.001 \\
(1.92)^{*}\end{array}$ & \\
\hline Disagreement & $\begin{array}{l}0.003 \\
(1.28)\end{array}$ & $\begin{array}{l}0.008 \\
(3.25)^{* * *}\end{array}$ & & & $\begin{array}{l}0.003 \\
(1.38)\end{array}$ & $\begin{array}{c}0.008 \\
(3.03)^{* * *}\end{array}$ & & \\
\hline Size & $\begin{array}{l}-0.001 \\
(1.37)\end{array}$ & $\begin{array}{l}-0.002 \\
(2.05)^{* *}\end{array}$ & $\begin{array}{l}-0.000 \\
(1.28)\end{array}$ & $\begin{array}{l}0.085 \\
(4.32)^{* * *}\end{array}$ & $\begin{array}{r}-0.002 \\
(1.66)^{*}\end{array}$ & $\begin{array}{c}-0.002 \\
(2.92)^{* * *}\end{array}$ & $\begin{array}{c}-0.001 \\
(1.50)\end{array}$ & $\begin{array}{c}0.085 \\
(4.34)^{* * *}\end{array}$ \\
\hline PrevFE & $\begin{array}{c}-0.002 \\
(0.96)\end{array}$ & & & & $\begin{array}{r}-0.002 \\
(1.00)\end{array}$ & & & \\
\hline ABS(PrevFE) & & $\begin{array}{l}0.005 \\
(3.25)^{* * *}\end{array}$ & $\begin{array}{l}0.004 \\
(6.78)^{* * *}\end{array}$ & $\begin{array}{c}-0.013 \\
(1.30)\end{array}$ & & $\begin{array}{c}0.005 \\
(3.30)^{* * *}\end{array}$ & $\begin{array}{c}0.004 \\
(6.74)^{* * *}\end{array}$ & $\begin{array}{c}-0.013 \\
(1.31)\end{array}$ \\
\hline Volatility & $\begin{array}{l}0.002 \\
(1.62)\end{array}$ & $\begin{array}{c}0.001 \\
(1.69)^{*}\end{array}$ & $\begin{array}{l}0.001 \\
(2.75)^{* * *}\end{array}$ & $\begin{array}{l}-0.007 \\
(0.59)\end{array}$ & $\begin{array}{c}0.002 \\
(1.68)^{*}\end{array}$ & $\begin{array}{l}0.001 \\
(1.61)\end{array}$ & $\begin{array}{c}0.001 \\
(2.73)^{* * *}\end{array}$ & $\begin{array}{c}-0.004 \\
(0.34)\end{array}$ \\
\hline Horizon & $\begin{array}{l}0.001 \\
(1.51)\end{array}$ & $\begin{array}{l}0.004 \\
(6.61)^{* * *}\end{array}$ & $\begin{array}{r}0.000 \\
(1.73)^{*}\end{array}$ & $\begin{array}{l}0.022 \\
(4.66)^{* * *}\end{array}$ & $\begin{array}{l}0.001 \\
(1.47)\end{array}$ & $\begin{array}{c}0.004 \\
(6.54)^{* * *}\end{array}$ & $\begin{array}{c}0.000 \\
(1.89)^{*}\end{array}$ & $\begin{array}{c}0.022 \\
(4.67)^{* * *}\end{array}$ \\
\hline Option & $\begin{array}{l}-0.006 \\
(1.60)\end{array}$ & $\begin{array}{l}-0.000 \\
(0.06)\end{array}$ & $\begin{array}{l}0.001 \\
(0.47)\end{array}$ & $\begin{array}{l}0.307 \\
(9.08)^{* * *}\end{array}$ & $\begin{array}{r}-0.006 \\
(1.52)\end{array}$ & $\begin{array}{c}-0.001 \\
(0.18)\end{array}$ & $\begin{array}{l}0.001 \\
(0.59)\end{array}$ & $\begin{array}{c}0.301 \\
(8.93)^{* * *}\end{array}$ \\
\hline
\end{tabular}




\begin{tabular}{|c|c|c|c|c|c|c|c|c|}
\hline$F$-test & $1.79 * *$ & $13.54 * * *$ & $21.47 * * *$ & $26.17 * * *$ & $1.84 * * *$ & $12.33 * * *$ & $18.64 * * *$ & $21.86 * * *$ \\
\hline Adj. $R^{2}$ & 0.04 & 0.20 & 0.26 & 0.30 & 0.04 & 0.21 & 0.27 & 0.31 \\
\hline Year and Ind. FE & Yes & Yes & Yes & Yes & Yes & Yes & Yes & Yes \\
\hline
\end{tabular}

Note: All coefficients relate to variables that have been standardized to assist interpretation. The sample comprises firms rated in the Board Shareholder Confidence Index with year ends between 1 January 2002 and 31 December 2007. Results are estimated using pooled Ordinary Least Squares methods with robust standard errors clustered by firm-month to control for heteroskedasticity. See Table 1 for variable definitions. $t$-statistics with standard errors clustered by firms in parentheses. $* p<0.1 ; * * p<0.05 ; * * *$ $p<0.01$ (one-tailed $t$-tests for hypothesised effects and two-tailed $t$-tests for control variables) 